ISSN 0103-5150

Fisioter. Mov., Curitiba, v. 27, n. 3, p. 319-327, jul./set. 2014

Licenciado sob uma Licença Creative Commons DOI: http://dx.doi.org.10.1590/0103-5150.027.003.A002

\title{
Importance of domestic guidelines for women with urinary incontinence
}

\author{
Importância das orientações domiciliares para \\ mulheres com incontinência urinária
}

\author{
Síssi Sisconeto de Freitas ${ }^{[a]}$, Maria Cristina Cortez Carneiro Meirelles ${ }^{[b]}$, \\ Adriana Clemente Mendonça ${ }^{[c]}$ \\ [a] Graduate, Universidade Federal do Triângulo Mineiro, Uberaba, MG - Brazil, e-mail: sissi-sf@hotmail.com \\ [b] PhD, professor, Universidade Federal do Triângulo Mineiro, Departamento de Fisioterapia Uberaba, MG - Brazil, e-mail: \\ marmeirelles@gmail.com \\ [c] PhD, professor, Universidade Federal do Triângulo Mineiro, Departamento de Fisioterapia Uberaba, MG - Brazil, e-mail: \\ adricm@terra.com.br
}

\begin{abstract}
Introduction: The importance of domestic guidelines as a help in the treatment of urinary incontinence (UI) is evident, but its influence on the quality of life (QoL) of incontinent women, when applied without supervision, is unknown. Objective: To evaluate the influence of domestic guidelines for the treatment of UI on the QoL of incontinent women. Methods: This is a quasi-experimental before and after study. Seventy one women with UI and a mean age of 53.47 ( \pm 14.21 ) years were assessed, instructed with the aid of an illustrative and explanatory folder and reassessed after six months using the King's Health Questionnaire (KHQ). KHQ data were analyzed using the Wilcoxon test for paired samples, with significance level of 5\%. Results: There was a statistically proven improvement in six of the eight domains and in six of the ten symptoms assessed $(\mathrm{p}<0.05)$. Conclusion: We conclude that the domestic guidelines for treatment of UI positively influenced the QoL of the women who participated in this study.
\end{abstract}

Keywords: Urinary incontinence. Quality of life. Physical therapy. Women's health. 


\section{Resumo}

Introdução: A importância das orientações domiciliares como coadjuvantes no tratamento da incontinência urinária (IU) é evidente, mas não se sabe qual sua influência sobre a qualidade de vida (QV) de mulheres incontinentes quando aplicadas sem supervisão. Objetivos: Avaliar a influência das orientações domiciliares para tratamento da IU sobre a QV de mulheres incontinentes. Métodos: Estudo quase-experimental do tipo antes e depois. Foram incluídas 71 mulheres com IU, 53,47 ( $\pm 14,21)$ anos orientadas com auxílio de um folder ilustrativo e explicativo e reavaliadas após seis meses com auxílio do King's Health Questionnaire (KHQ). Os dados do KHQ foram analisados pelo teste de Wilcoxon para amostras pareadas, com nível de significância de 5\%. Resultados: Houve melhora estatisticamente comprovada em seis dos oito domínios e em seis dos dez sintomas avaliados $(p<0,05)$. Conclusão: Concluímos que as orientações domiciliares para tratamento da IU influenciaram positivamente a QV das mulheres no grupo estudado.

Palavras-chave: Incontinência urinária. Qualidade de vida. Fisioterapia. Saúde da mulher.

\section{Introduction}

Urinary incontinence (UI) is defined by the International Continence Society (ICS) as the involuntary leakage of urine, which may cause social and hygiene problems (1). Age, sex, as well as physical, mental and general health conditions directly influence the prevalence and incidence of UI (2). In Brazil, prevalence studies focus on specific populations $(2,3$, $4,5)$. Up to now, there is no significant study assessing UI prevalence in population-based surveys and thus enabling the analysis of incidence rates in the national population. However, several authors have indicated a substantial number of incontinent women at various stages of the life cycle $(6,7,8,9,10)$.

People who have urine leakage may present many symptoms, including stress urinary incontinence (SUI), urgency urinary incontinence (UUI), mixed urinary incontinence (MUI) or urinary incontinence while changing posture, during sexual intercourse, among others (1). This diversity of symptoms together with the level of activity and sociocultural integration of these women are factors directly related to the impact of UI on their quality of life (QoL) (11).

The diagnosis of UI is based on clinical history, physical examination and urodynamic study. Voiding diary, pad test and QoL questionnaires complement the diagnosis (12). The ICS recommends the use of specific tools such as the King's Health Questionnaire (KHQ) to quantify the influence of UI on QoL as well as to quantify the effects of therapy (1).

The therapeutic approach consists of surgical and conservative treatment. It is chosen based on the severity and etiology of the UI. There are several surgical techniques available. However, like any surgery, they carry risks, increase spending and not always avoid the association with other treatments (13). Conservative treatment is based on pharmacological and physical therapy resources (14). The effectiveness of the first is limited to some cases and it has considerable side effects. Because it has low cost and virtually no side effects, the latter should be the first choice of treatment or it should be indicated in combination with pharmacological treatment $(15,16)$.

Several studies indicate the effectiveness of pelvic floor training (PFT), which is widely used in physical therapy $(17,18,19)$. The effectiveness of this training, its low cost of implementation and the fact that it has virtually no side effects turned it into a strategy for the treatment of UI in health care programs conducted at Basic Healthcare Units. These programs are often carried out with the aid of booklets and lessons. Satisfactory results are observed even among populations who are not effectively engaged with treatment, either because they refuse to accept the problem, are illiterate or low-income (18).

The aim of this study was to evaluate the influence of domestic guidelines for the treatment of UI on the QoL of incontinent women.

\section{Methods}

This quasi-experimental before and after study was approved by the Research Ethics Committee of the Federal University of Triangulo Mineiro under protocol 
number 1619. It was conducted from April 2010 to August 2011 at the Basic Healthcare Units, the Center for Integral Attention to Women's Health (CAISM) and the Maria da Glória Outpatient Clinic (UFTM).

Women with UI were identified during lectures on the prevention and treatment of UI and held at facilities of the public healthcare network. All women with urinary incontinence complaints who had not had or were in physical therapy and accepted to participate were included in this study. Exclusion criteria were: age below 18 years, pregnancy, report of neurological alterations, and cognitive deficits that could compromise the study. All participants read and signed the informed consent form.

In the initial approach, we collected personal and sociodemographic data, gynecological, obstetric and sexual history, and characteristics and data related to UI, associated diseases and lifestyle habits. At this moment and about six months later, we applied the KHQ, which is composed of 32 questions. Eleven of these questions constitute a scale of symptoms: urinary frequency, nocturia, urinary urgency, urge incontinence, stress urinary incontinence, nocturnal enuresis, UI during sexual intercourse, frequent urinary tract infections, bladder pain, difficulty urinating, as well as a space to mention other symptoms related to UI. The remainder are divided into eight domains, which are: general health perception, impact of UI, limitations of daily activities, physical and social limitations, personal relationships, emotion, sleep/energy and severity/coping measures. The (numeric) values of each question are summed or calculated by mathematical formula and result in values between zero and 100 for each domain. The higher the score, the worse the perception of QoL. The KHQ was applied in the form of interview because there were semi-illiterate and illiterate women in the sample.

Women, individually, were provided general guidance about UI (definition, types of UI and aggravating factors), prevention and treatment modalities. With the aid of an explanatory folder (available at: http:// www.uftm.edu.br/upload/noticias/IU_versao_9.pdf), women received the following instructions: anatomy and functions of the pelvic floor; and exercises for the activation of the pelvic floor muscles. The exercises consisted of sustained submaximal contractions and unsustained maximal contractions. Initially, three sets of ten repetitions should be performed three times a day in the supine, sitting and standing positions. The women received only verbal guidance. There was no prior physical examination of the pelvic floor.
The women were instructed to perform these exercises on a daily basis, increasing the time of sustained submaximal contractions and the number of series according to their evolution. However, they should be careful not to compromise quality while "increasing quantity".

The scores for the domains and symptoms of the QoL assessment were compared using the Wilcoxon test for paired samples, with significance level of 0.05 . Average, standard deviation, and absolute and relative frequencies were evaluated.

\section{Results}

71 women with urinary leakage complaints were evaluated and re-evaluated. The average age of participants was $53.47 \pm 14.21$ years. Their socio-demographic and obstetric data are shown in Table 1.

Data regarding the symptoms score before and after guidance was provided are shown in Figure 1. Among the symptoms that most affected women before guidance are: urinary urgency (57.75\%), urge incontinence $(52.11 \%)$, and stress urinary incontinence (SUI, 52.11\%). After guidance, those symptoms that most bothered these women were: urge incontinence (35.21\%), urinary urgency $(32.39 \%)$ and increased urinary frequency $(26.76 \%)$. Significant improvements were observed in six of the ten evaluated symptoms (urinary frequency, nocturia, urinary urgency, urge incontinence, stress urinary incontinence and nocturnal enuresis) ( $\mathrm{p}<0.05)$.

Table 2 shows the QoL scores before and after guidance was provided, with significant improvement in six of eight domains (impact of incontinence, limitations of daily activities, physical and social limitations, emotions, sleep/energy and severity/coping measures) $(\mathrm{p}<0.05)$.

\section{Discussion}

The average age of participants (53.47 years) was similar to that found in other studies conducted with women with UI $(20,21)$. This age probably predominates among women with UI due to the physiological changes related to aging and the postmenopausal period, such as hormonal decline and decrease in muscle tone, which are important predisposing factors to urinary leakage $(10),(22,23)$. 
Table 1 - Socio-demographic and obstetric characteristics of women with UI

(To be continued)

\begin{tabular}{|c|c|c|}
\hline Variables & Average $(n=71)$ & Standard deviation \\
\hline Age (years) & 53.48 & 14.21 \\
\hline $\mathrm{BMI}\left(\mathrm{kg} / \mathrm{m}^{2}\right)$ & 28.38 & 5.26 \\
\hline Marital status & Absolut frequency ( $n$ ) & Relative frequency (\%) \\
\hline Married & 36 & 50.70 \\
\hline Single & 12 & 16.90 \\
\hline Widow & 12 & 16.90 \\
\hline Divorced & 11 & 15.49 \\
\hline Education level & Absolut frequency (n) & Relative frequency (\%) \\
\hline Complete primary education & 41 & 57.74 \\
\hline Incomplete primary education & 7 & 9.85 \\
\hline Complete secondary education & 15 & 21.12 \\
\hline Incomplete secondary education & 3 & 4.22 \\
\hline Incomplete higher education & 1 & 1.40 \\
\hline Semi-illiteracy & 1 & 1.40 \\
\hline Illiteracy & 3 & 4.22 \\
\hline Monthly income & Absolut frequency ( $n$ ) & Relative frequency (\%) \\
\hline$\leq 2$ minimum wages & 42 & 59.15 \\
\hline 2 to 4 minimum wages & 19 & 26.76 \\
\hline 4 to 10 minimum wages & 9 & 12.67 \\
\hline$>10$ minimum wages & 1 & 1.40 \\
\hline Parity & Absolut frequency (n) & Relative frequency (\%) \\
\hline Nulliparous & 1 & 1.40 \\
\hline 1 to 3 deliveries & 41 & 57.74 \\
\hline$\geq 4$ deliveries & 29 & 40.84 \\
\hline Vaginal deliveries & Absolut frequency (n) & Relative frequency (\%) \\
\hline 0 & 12 & 16.90 \\
\hline 1 to 2 & 27 & 38.02 \\
\hline$\geq 3$ & 30 & 42.25 \\
\hline Not reported & 2 & 2.81 \\
\hline Cesarean deliveries & Absolut frequency $(n)$ & Relative frequency (\%) \\
\hline 0 & 35 & 49.29 \\
\hline 1 to 2 & 29 & 40.84 \\
\hline
\end{tabular}


Table 1 - Socio-demographic and obstetric characteristics of women with UI

(Conclusion)

\begin{tabular}{lcc}
\hline Cesarean deliveries & Absolut frequency (n) & Relative frequency (\%) \\
\hline$\geq 3$ & 5 & 7.04 \\
Not reported & 2 & 2.81 \\
\hline
\end{tabular}

Source: Research data.

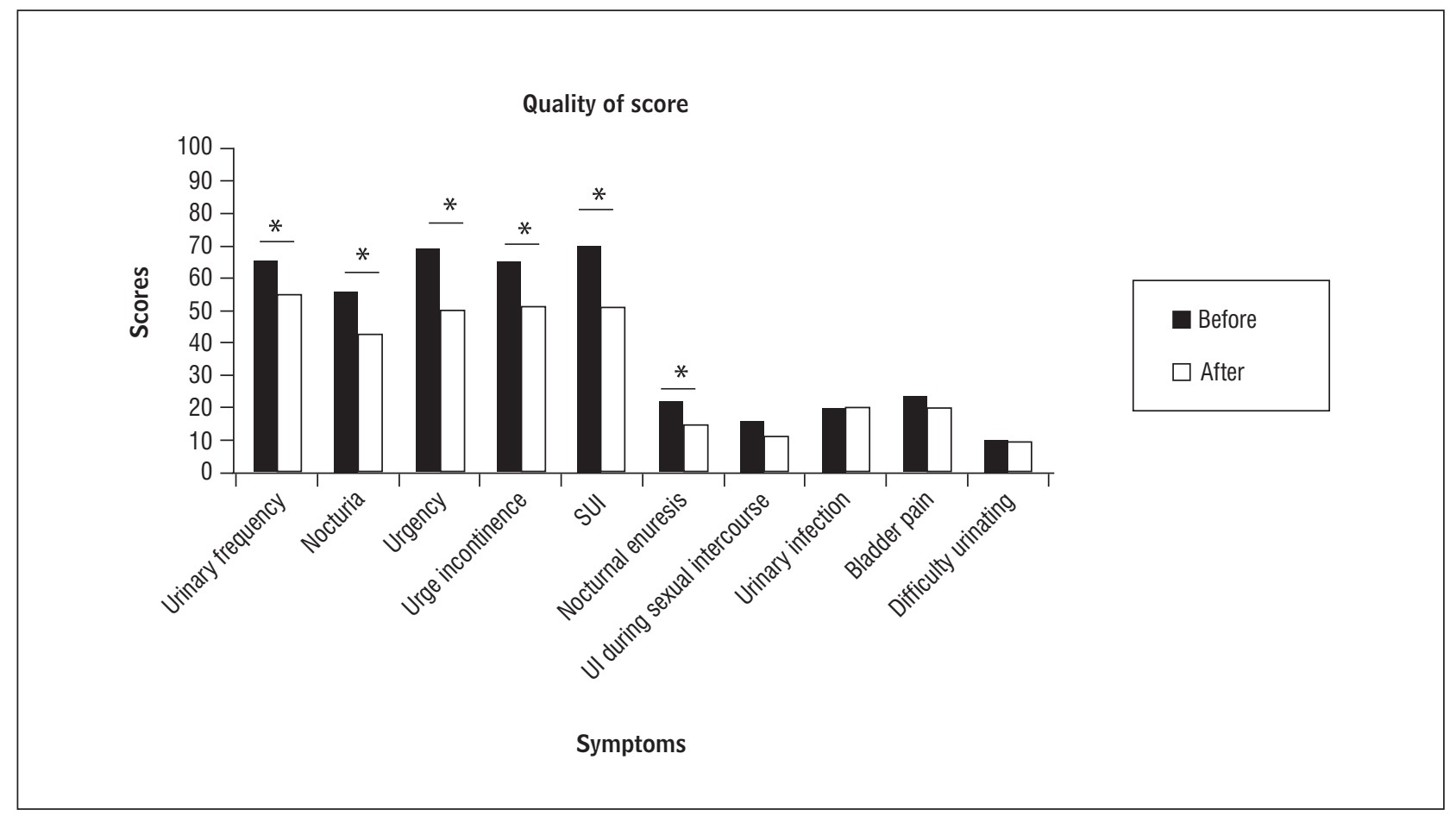

Figure 1 - Symptoms scores before and after guidance

Source: Research data.

Table 2 - Variations of the domains before and after guidance

(To be continued)

\begin{tabular}{lccc}
\hline KHQ domains & \multicolumn{1}{c}{ Before } & After & \multicolumn{1}{c}{$\mathbf{p}^{*}$} \\
\cline { 2 - 3 } General health perception & \multicolumn{2}{c}{ Average \pm Standard deviation } & \\
\cline { 2 - 3 } Impact of incontinence & $40.14 \pm 20.04$ & $35.56 \pm 24.52$ & 0.1073 \\
Limitations of daily activities & $57.03 \pm 35.32$ & $43.90 \pm 36.38$ & $0.0079^{*}$ \\
Physical and social limitations & $39.39 \pm 35.42$ & $25.17 \pm 33.40$ & $0.0008^{*}$ \\
Personal relationships & $32.49 \pm 32.64$ & $19.17 \pm 27.53$ & $<0.0001^{*}$ \\
Emotions & $15.25 \pm 29.33$ & $13.34 \pm 27.80$ & 0.5115 \\
Sleep/energy & $41.63 \pm 35.18$ & $32.03 \pm 34.47$ & $0.0461^{*}$ \\
& $38.93 \pm 30.38$ & $28.75 \pm 26.54$ & $0.0030^{*}$
\end{tabular}


Table 2 - Variations of the domains before and after guidance

(Conclusion)

\begin{tabular}{|c|c|c|c|}
\hline KHQ domains & Before & After & $p^{*}$ \\
\hline & \multicolumn{2}{|c|}{ Average \pm Standard deviation } & \\
\hline Severity/coping measures & $46.65 \pm 28.63$ & $33.73 \pm 25.30$ & $<0.0001^{*}$ \\
\hline
\end{tabular}

Note: ${ }^{*} p<5 \%$ (Wilcoxon test).

Source: Research data.

Knorst et al. (20) and Figueiredo et al. (21) reported results similar to ours, regarding the education level of women with UI. Most women (67.59\%) were found to have complete or incomplete primary education. However, we cannot say that there is a correlation between educational level and incidence of UI. We believe that the low educational level found is due to the target audience of these studies, which were composed by public health service users.

Data on monthly income are not always presented together with factors influencing UI $(20,21)$. In the study by Sacomori et al. (24) the average income per family member was 1.25 minimum wages. We believe that the fact that most women have a monthly income lower or equal to 2 minimal wages is compatible with public health service users.

Although socioeconomic data such as educational level and monthly income are reported in some studies $(20,21),(24)$, no correlation between these data and the incidence or severity of UI was mentioned.

Most women in UI studies are married $(20,21)$, (24). This may cause the UI to have a greater impact on the lives of women who maintain stable relationships and have an active sex life, since the leakage of urine and its associated smell can generate embarrassment (11).

In our study, the mean body mass index (BMI) was indicative of overweight, and the average number of pregnancies per woman (four pregnancies) are close to the results of Amaro et al. (25). The latter analyzed the prevalence of and risk factors for UI, and found higher BMI in a group of incontinent women, when compared to a group of women without urinary leakage who had an average of 3.6 pregnancies. Thus, we found several associated risk factors for the development of UI in the group evaluated.

In this study, we observed a significant improvement in most domains and symptoms after guidance was provided. This improvement was also evidenced in the study by Rett et al. (26), in which 26 women with predominant clinical complaints of SUI were treated during 12 sessions of kinesiotherapy and electromyographic biofeedback. Although most domains have shown improvements, the personal relationships domain showed no change after the intervention. This also occurred in our study: we observed no change in this domain after guidance was provided, which diverges somewhat from the literature.

Since this domain involves aspects of family and sexual life, it is likely that the intensity of urinary leakage was not enough to affect family relationships and sex life, or yet, which in our study is more likely to be the case due to the average age of the studied women, some of these women probably did not have an active sex life anymore. This can be observed in the scale of urinary symptoms, in which only 18 (25\%) of 71 evaluated women reported some level of urinary incontinence during intercourse before guidance was provided.

The KHQ is the most used tool to measure the influence of both surgical and therapeutic approaches on the QoL of women with UI $(26,27,28)$.

In the therapeutic approach to UI, pelvic floor muscles training has been the resource of first choice because it has low cost, no contraindications and achieves good results $(29,30)$. This training is based on raising awareness, automation and exercises for fast-contraction fibers, which treat SUI, and for slow-contraction fibers, which prevent urge incontinence (31).

The exercises taught in this study contemplated these concepts, since they were designed to meet the needs of a group of incontinent women without a specific diagnosis as to the type of UI. During the guidance sessions, one of our goals was to raise the awareness to the pelvic floor, using pictures that helped explain anatomical and functional features 
of this region, as recommended by several authors $(31,32,33)$.

The exercises performed associated physical postures, breathing and movements of the lower limbs with the contraction of the pelvic floor. These contractions followed the principle that the most effective training occurs when fast contractions are performed with maximum intensity and sustained contractions are carried out with submaximal intensity. They can reach a subjective improvement between 56 and $70 \%$ (29).

Despite the positive results obtained in our study, the failure to adopt a methodology to classify the type of UI and to establish the percentage, even if subjective, of functional improvement of the pelvic floor was considered to be a limitation. Studies conducted at public healthcare network facilities often have this limitation. This is the case of the study by Sacomori et al. (24), in which the presence of UI was determined by self-report through a questionnaire and UI was not classified, as it occurred in this study.

According to Santos and Simões (34), measuring and assessing the QoL of an individual or a population is hard work. Accurately and effectively interfering also seems to be complicated. However, there is an ever-growing concern about the QoL of the population, as recommended by the World Health Organization (2). Therefore, studies that take into account the assessment of QoL should be valued.

In the case of UI, we know that the influence on QoL depends on the activity level of sociocultural integration and age. Even though the impact of UI on QoL is large, it is still considered by some women and healthcare professionals as an inevitable result of aging in women. Therefore, this topic deserves to be treated as a public health issue (10), (35).

Sacomori et al. (24) identified a high prevalence of UI in women seeking to undergo screening test for cervical cancer in public healthcare facilities. This fact justifies the conduction of preventive approaches in these settings. In this context, we consider our study to be extremely important, because it achieved improvements in the QoL of incontinent women from public health facilities through simple preventive and health promotion measures.

In literature there are many reports of the positive impact of pelvic floor muscles strengthening on the QoL of incontinent women, and the provision of domestic guidelines are part of this approach. However, in accordance with our best knowledge, no reports were found on its real benefits when performed without supervision and association with physical therapy.

Even though $100 \%$ compliance on the part of the volunteers is often not achieved, as occurs in most unsupervised domestic guidelines (18), we believe, based on the findings of our study, that this guidance can have a positive impact on the QoL of women with UI.

Initiatives to promote the discussion of this topic, as well as the possibility of home management of UI, as in this study, should be performed and improved in order to become additional resources for coping with UI.

\section{Conclusion}

We conclude that providing domestic guidelines for treating UI positively influenced the UI domains (impact of incontinence, limitations of daily activities, physical and social limitations, emotions, sleep/energy, and severity/coping measures) and symptoms (urinary frequency, nocturia, urgency, urge incontinence, SUI and nocturnal enuresis), improving the QoL of the women who participated in this study.

\section{Acknowledgments}

To the FAPEMIG for the financial support and to the public physiotherapists of the city of Uberaba for advertising and participating in this study.

\section{References}

1. Haylen BT, Ridder D, Freeman RM, Swift SE, Berghmans B, Lee J, et al. An International Urogynecological Association (IUGA)/International Continence Society (ICS) joint report on the terminology for female pelvic floor dysfunction. Int Urogynecol J. 2010;21(1):5-26.

2. Silva APM, Santos VLCG. Prevalência da incontinência urinária em adultos e idosos hospitalizados. Rev Esc Enferm USP. 2005;39(1):36-45. 
3. Santos CRS, Santos VLCG. Prevalência da incontinência urinária em amostra randomizada da população urbana de Pouso Alegre, Minas Gerais, Brasil. Rev LatinoAm Enfermagem. 2010 (cited 2012 Feb 20);18(5):(08 telas). Available from: http://www.scielo.br/pdf/ rlae/v18n5/pt_10.pdf

4. Tamanini JTN, Lebrão ML, Duarte YAO, Santos JLF, Laurenti R. Analysis of the prevalence of and factors associated with urinary incontinence among elderly people in the Municipality of São Paulo, Brazil: SABE Study (Health, Wellbeing and Aging).Cad Saude Publica. 2009;25(8):1756-62.

5. Motta DM, Victora CG, Hallal PC. Investigação de disfunção miccional em uma amostra populacional de crianças de 3 a 9 anos. J Pediatr. 2005;81(3):225-32.

6. Almeida PP, Machado LRG. A prevalência de incontinência urinária em mulheres praticantes de jump. Fisioter Mov. 2012;25(1):55-65.

7. Virtuoso JF, Mazo GZ, Menezes EC. Incontinência urinária e função muscular perineal em idosas praticantes e não praticantes de atividade física regular. Rev Bras Fisioter. 2011;14(4):310-7.

8. Valeton CT, Amaral VF. Evaluation of urinary incontinence in pregnancy and postpartum in Curitiba Mothers Program: a prospective study. Int Urogynecol J. 2011;22(7):813-8.

9. Dellú MS, Zácaro PMD, Schmitt ACB. Prevalência de sintomas urinários e fatores obstétricos associados em mulheres adultas. Rev Bras Fisioter. 2008; 12(6):482-7.

10. Guarisi T, Neto AMP, Osis MJ, Pedro AO, Paiva LHC, Faúndes A. Incontinência urinária entre mulheres climatéricas brasileiras: inquérito domiciliar. Rev Saude Publica. 2001;35(5):428-35.

11. Aslan E, Beji NK, Coskun A, Yalcin O. An assessment of the importance of pad testing in stress urinary incontinence and the effects of the incontinence on the life quality of women. Int Urogynecol J. 2003; 14(5):316-20.

12. Feldner Jr. PC, Sartori MGF, Lima GR, Baracat EC, Girão MJBC. Diagnóstico clínico e subsidiário da incontinência urinária. Rev Bras Ginecol Obstet. 2006; 28(1):54-62.
13. Chiapara TR, Cacho DP, Alves AFD. Incontinência urinária feminina: assistência fisioterapêutica e multidisciplinar. São Paulo: LMP; 2007.

14. Arruda RM, Sousa GO, Castro RA, Sartori MGF, Baracat EC, Girão MJBC. Hiperatividade do detrusor: comparação entre oxibutinina, eletroestimulação funcional do assoalho pélvico e exercícios perineais: estudo randomizado. Rev Bras Ginecol Obstet. 2007;29(9):452-8.

15. Knorst MR, Cavazzotto K, Henrique M, Resende TL. Intervenção fisioterapêutica em mulheres com incontinência urinária associada ao prolapso de órgão pélvico. Rev Bras Fisioter. 2012;16(2):102-7.

16. Toledo DD, Dedicação AC, Saldanha ME, Haddad M, Driusso P. Physical Therapy treatment in incontinent women provided by a public health service. Fisioter Mov. 2011;24(2):327-35.

17. Franco MM, Souza FO, Vasconcelos ECLM, Freitas MMS, Ferreira CHJ. Avaliação da qualidade de vida e da perda urinária de mulheres com bexiga hiperativa tratadas com eletroestimulação transvaginal ou do nervo tibial. Fisioter Pesqui. 2011;18(2):145-50.

18. Marques KSF, Freitas PAC. A cinesioterapia como tratamento da incontinência urinária na unidade básica de saúde. Fisioter Mov. 2005;18(4):63-67.

19. Pereira VS, Correia GN, Driusso P. Individual and group pelvic floor muscle training versus no treatment in female strees urinary incontinence: a randomized controlled pilot study. Eur J Obstet Gynecol Reprod Biol. 2011;159(2):465-71.

20. Knorst MR, Resende TL, Goldim JR. Perfil clínico, qualidade de vida e sintomas depressivos de mulheres com incontinência urinária atendidas em hospital-escola. Rev Bras Fisioter. 2011;15(2):109-16.

21. Figueiredo EM, Lara JO, Cruz MC, Quintão DMG, Monteiro MVC. Perfil sociodemográfico e clínico de usuárias de serviço de fisioterapia uroginecológica da rede pública. Rev Bras Fisioter. 2008;12(2):136-42.

22. Souza CEC, Lima RM, Bezerra LMA, Pereira RW, Moura TK, Oliveira RJ. Estudo comparativo da função do assoalho pélvico em mulheres continentes e incontinentes na pós menopausa. Rev Bras Fisioter. 2009;13(6):535-41. 
23. Reis RB, Cologna AJ, Martins ACP, Tucci Jr. S, Suaid HJ. Incontinência urinária no idoso. Acta Cir Bras. 2003;18(5):47-51.

24. Sacomori C, Negri NB, Cardoso FL. Incontinência urinária em mulheres que buscam exame preventivo de câncer de colo uterino: fatores sociodemográicos e comportamentais. Cad Saude Publica. 2013; 29(6):1251-9.

25. Amaro JL, Macharelli CA, Yamamoto H, Kawano PR, Padovani CR, Agostinho AD. Prevalence and risk factors for urinary and fecal incontinence in Brazilian women. Int Braz J Urol. 2009;35(5):592-7.

26. Rett MT, Simões JA, Herrmann V, Gurgel MSC, Morais SS. Qualidade de vida em mulheres após tratamento da incontinência urinária de esforço com fisioterapia. Rev Bras Ginecol Obstet. 2007;29(3):134-40.

27. Auge AP, Zucchi CM, Costa FMP, Nunes K, Cunha LPM, Silva PVF, et al. Comparações entre os índices de qualidade de vida em mulheres com incontinência urinária submetidas ou não ao tratamento cirúrgico. Rev Bras Ginecol Obstet. 2006;28(6):352-7.

28. Bidmead J, Cardozo L, McLellan A, Khullar V, Kelleher C. A comparison of the objective and subjective outcomes of colposuspension for stress incontinence in women. BJOG. 2001;108(4):408-13.

29. Bo K. Is there still a place for physiotherapy in the treatment of female incontinence? EAU-EBU Update Series. 2003;1(3):145-53.
30. Seo JT, Yoon H, Kim YH. A randomized prospective study comparing new vaginal cone and FES-biofeedback. Yonsei Med J. 2004;45(5):879-84.

31. Ferreira CHJ. Fisioterapia na saúde da mulher: teoria e prática. Rio de Janeiro: Guanabara Koogan; 2011.

32. Moreno AL. Cinesioterapia do assoalho pélvico. In: Moreno AL. Fisioterapia em uroginecologia. São Paulo: Manole; 2004. p. 115-20.

33. Baracho E, Moreno AC. A reeducação da musculatura do assoalho pélvico como método de tratamento conservador da incontinência urinária. In: Baracho E. Fisioterapia aplicada à obstetrícia, uroginecologia e aspectos da mastologia. 4. ed. Rio de Janeiro: Guanabara Koogan; 2007. p. 430-47.

34. Santos ALP, Simões AC. Educação física e qualidade de vida: reflexões e perspectivas. Saúde Soc. 2012; 21(1):181-192.

35. Berlezi EM, Bem AD, Antonello C, Leite MT, Bertolo EM. Incontinência urinária em mulheres no período pósmenopausa: um problema de saúde pública. Rev Bras Geriatr Gerontol. 2009;12(2):159-73.

Received: 01/23/2014

Recebido: 23/01/2014

Approved: 07/02/2014

Aprovado: 02/07/2014 